\title{
Economics: A Moral Inquiry with Religious Origins
}

\section{Citation}

Friedman, Benjamin M. 2011. Economics: a moral inquiry with religious origins. The American Economic Review 101(3): 166-170.

\section{Published Version}

doi:10.1257/aer.101.3.166

\section{Permanent link}

http://nrs.harvard.edu/urn-3:HUL.InstRepos:8895184

\section{Terms of Use}

This article was downloaded from Harvard University's DASH repository, and is made available under the terms and conditions applicable to Open Access Policy Articles, as set forth at http:// nrs.harvard.edu/urn-3:HUL.InstRepos:dash.current.terms-of-use\#OAP

\section{Share Your Story}

The Harvard community has made this article openly available.

Please share how this access benefits you. Submit a story.

\section{Accessibility}


January, 2011

For: AER Papers \& Proceedings

\title{
ECONOMICS: A MORAL INQUIRY WITH RELIGIOUS ORIGINS
}

\author{
Benjamin M. Friedman \\ William Joseph Maier Professor of Political Economy \\ Harvard University
}

\section{Contact information:}

\author{
Benjamin M. Friedman \\ Harvard University, Department of Economics \\ Littauer Center 127 \\ Cambridge, MA 02138 \\ Tel.: $\quad 617-495-4246$ \\ Fax: 617-495-7730 \\ E-mail: $\quad$ bfriedman@ harvard.edu
}


Its secure foundation as an empirically based discipline notwithstanding, economics from its inception has also been a moral science. Adam Smith's academic appointment was as professor of moral philosophy, and not only his earlier Theory of Moral Sentiments but the Wealth of Nations too reflects it. Both books are replete with analyses of individuals' motivations and psychological states, and the ways in which what we now call "economic" activity, carried out in inherently social settings, enables them to lead satisfying lives or not. Even the division of labor, which Smith hailed (from the very first sentence of the Wealth of Nations) as the key to enhanced productivity, is subject to explicitly moral reservations - because it erodes individuals' capacities for "conceiving any generous, noble or tender sentiment" and for judging either "the ordinary duties of private life" or "the great and extensive interests" of the nation. The greatest concern throughout is to foster the well-being of what Smith calls "the great body of the people." Material living standards matter for themselves, but, more importantly, they are essential for both individual happiness and public advancement: "No society can surely be flourishing and happy of which the far greater part of the members are poor and miserable."1

As if in validation of Smith's concerns about the division of labor, the moral aspect of our discipline is often ignored, and sometimes even deliberately set aside, in today's ever narrower and more specialized forms of economic analysis; but it was there from the outset, and it is widely recognized nonetheless. By contrast, what is not generally understood - indeed, what contradicts most current-day interpretations of the origins of economics as an independent intellectual discipline - is the influence on the work of Smith and other early "economists" stemming from thinking about matters not just moral but religious in the traditional sense.

The commonplace view today is that the emergence of "economics" out of the European Enlightenment of the $18^{\text {th }}$ century was an aspect of the more general movement toward secular 
modernism in the sense of a historic turn in thinking away from a God-centered universe, toward what we broadly call humanism. To the contrary, I suggest that the all-important transition in thinking that we rightly identify with Adam Smith and his contemporaries and followers - the key transition that gave us economics as we now know it - was powerfully influenced by thencontroversial changes in religious belief in the English-speaking Protestant world in which they lived. Further, those at-the-outset influences of religious thinking not only fostered the subsequent spread of Smithian thinking, especially in America, but shaped the course of its reception. The ultimate result was a variety of fundamental resonances between economic thinking and religious thinking that continue to influence our public discussion of economic issues, and our public debate over economic policy, today.

The idea of a religious influence on Adam Smith's thinking, or on that of his contemporaries and followers, will probably strike many readers of the American Economic Review as implausible. As far as one can tell from the available biographical sources, Smith, like many Enlightenment figures, was at most what American students of that time think of as a Jeffersonian deist. There is little evidence of Smith's active religious participation, much less religious enthusiasm.

But Smith and his contemporaries lived in a time when religion was both more pervasive and more central than anything we know in today's Western world. In the Britain of Smith's day, religion was coterminous with politics. The Moderates and the Evangelicals within the Church of Scotland were of course debating matters of theology. But their debates were also about political matters: issues of liberty such as the allowable degree of toleration, issues of church authority and therefore of political influence, and issues of patronage in the awarding of 
church livings, honors and other offices. In a far more dramatic way, in the prior century the issues at stake in the English civil war, the Puritan Commonwealth under Cromwell, the Stuart restoration, and the Glorious Revolution of 1688 had all turned crucially on religious contention. But Smith witnessed the phenomenon as well; he was 22 years old when the Highland rebellion of 1745 brought the same deadly mix of religion and politics to Scotland.

Perhaps more important for purposes here, intellectual life was also far less segmented then. Not only were the sciences and the humanities (to use today's language) normally discussed in the same circles and often by the same individuals, but theology too was part of the ongoing discussion. Part of what Smith taught, as Professor of Moral Philosophy at Glasgow, was "natural theology." In turn, one of the principal texts used for natural theology instruction in Scotland in the $18^{\text {th }}$ century was Newton's Principia Mathematica. Likewise, when the "literati" of the Scottish Enlightenment dined out, their regular interlocutors included professional divines. Of the 100+ members of the Select Society, Edinburgh's elite dining and debate club to which Smith, David Hume, Adam Ferguson and most of the distinguished Scottish figures of that day belonged, 14 were ministers (including Ferguson, who also held the chair of moral philosophy in Edinburgh, as well as William Robertson, the leader of the Moderate party in the Scottish church and also principal of Edinburgh University).

Hence Smith and his contemporaries would continually have been exposed to what were then current debates, tensions and new ideas in theology, in the same way that economists in university life today might be exposed to new thinking in physics, or biology, or demography. And in the same way that economists today often draw on ideas from those other lines of inquiry - think of "gravity" models of trade, or "penetration" models of competition, or "migration" 
models of technology transfer - these $18^{\text {th }}$ century thinkers who created what became the field of economics could easily have been influenced by what they heard, and read, and saw, of religious thinking. To be clear, the suggestion here is most certainly not that Smith, or any of the other "economic" thinkers of his day, self-consciously sought to bring religious principles to bear on what they thought and wrote. Rather, the theological controversies to which they were exposed were an influence on the basic view of man and the world - their "pre-analytic vision," to use Schumpeter's name for it - that they brought to their new thinking.

And it was that new thinking that gave us economics as the intellectual discipline that we know today. The central theorem underlying modern Western economics - the idea that we know as Adam Smith's “invisible hand” (even though Smith's use of the phrase, only once in the Theory of Moral Sentiments and once again in the Wealth of Nations, was neither original nor so specific) - is that behavior motivated merely by individuals' self-interest can, and under the right conditions will, lead to beneficial outcomes not merely for the individual(s) concerned but for others as well. Although there were antecedents (most obviously in the writings of Pierre Nicole, whose ideas also had a clearly identifiable origin in theological thinking, in his case Jansenist/Augustinian), ${ }^{2}$ the idea, especially in the form in which Smith advanced it, was new and it proved powerful.

At the beginning of the $18^{\text {th }}$ century, people who thought about such matters sometimes did and sometimes didn't ascribe to individuals the ability to perceive what actions and pursuits were in their own self-interest. But there was no sense that their pursuing that self-interest, even if they perceived it correctly, had any broader beneficial consequences. Indeed, the standard adjective used to characterize individual behavior motivated by self-interest was "vicious." 
The transition began in earnest with Bernard Mandeville's publication of the Fable of the Bees, first in 1714 and then, in revised form, in 1723. As is well known, Mandeville had the basic insight that pursuit of individual self-interest might lead to more generally favorable outcomes. But he did not fully work out this idea, nor the conditions under which it would play out. As his subtitle emphasized - "Private Vices, Publick Benefits"- he therefore continued to regard such behavior as “vicious." But Mandeville's Fable led to widespread debate, and much of what Hume, Francis Hutcheson and others wrote about such matters during the middle two quarters of the century was in reaction to Mandeville.

Smith's Wealth of Nations, published in 1776, achieved the full working out of the private-interest-leads-to-public-good idea as it has come down to us: individuals do correctly perceive their self-interest (in their roles as producers, although not necessarily as consumers); their desire to pursue their self-interest is a fundamental aspect of human nature; their doing so under the right conditions leads to outcomes that are optimal more broadly; and the key condition that allows these more broadly optimal outcomes to ensue is market competition. Not surprisingly, with the Wealth of Nations the vocabulary of "vice" and "vicious" is finally gone. By the end of the century Smith's idea was well known and broadly accepted.

What does all this have to do with religious thinking?

The central thrust of the Latitudinarian debate within the Church of England, which was at its height in the half-century or so before Mandeville's Fable (Mandeville was Dutch, but he lived in London and wrote in English), as well as of the Moderates-versus-Evangelicals debate in Scotland during much of Smith's adult lifetime, was a highly significant and contentious change in thinking that many religious historians have called "the decline of Calvinism"” - although for 
most non-specialists it may help to call it the decline of orthodox Calvinism. Three key elements in this transition were, at the very least, strikingly congruent with aspects of the transition from dismissal of the "vicious" pursuit of self-interest (which people may not have perceived correctly anyway) to recognition that such behavior would, under the right conditions, lead to broadly beneficial outcomes: (1) Orthodox Calvinists believed in the "utter depravity" of all individuals; their opponents within the English-speaking Protestant world mostly believed in the inherent goodness (and potential eligibility for salvation) of all individuals. (2) Orthodox Calvinists believed in predestination, with no role for human choice or action to affect who is saved and who is not; their opponents believed not only that anyone can potentially be saved but that individuals' choices and actions - human agency - play a role in this determination. As John Tillotson, the Latitudinarian Archbishop of Canterbury appointed in the wake of the Glorious Revolution, put it, people can "co-operate" in their own salvation, and "God can not be properly said to aid and assist those who do nothing themselves" in the matter. ${ }^{4}$ (3) Orthodox Calvinists believed that the sole reason man exists is the glorification of God; their opponents believed that human happiness is also a legitimate, divinely intended end.

While the mapping from these changes in religious thinking to the subsequent transition in economic thinking is hardly exact, there is a striking coherence nonetheless. The belief that men and women are born with an inherent goodness is surely more suggestive that they can understand their self-interest and can be of benefit to others, especially if human happiness is a divinely warranted end of man's existence, than if they are utterly depraved in the religious/moral sense. The further belief that all men and women are potentially eligible for salvation - and, further, that human agency is a part of what enables that salvation - is clearly more suggestive 
that individuals' acting in their perceived self-interest can improve not only their lives but those of their fellow creatures too, compared to the predestinarian belief that only few are saved and human agency has no bearing on the matter.

Yet a further change in religious thinking, playing out at roughly the same time though not part of the Calvinist/anti-Calvinist debate as such, concerned man's future on earth. In short, while those who came to be known as "pre-millennialists" exhibited an eschatological pessimism, believing that only the second coming and the resulting destruction of the world as we know it could lead to any essential improvement, the newer "post-millennialists" believed that the thousand years of blissful existence foretold in the Bible would be part of human history and, further, that human agency has a role in bringing it about. This belief, that "progress" in living conditions brought about by human agency not only is possible but helps bring the millennium nearer in time, is likewise far more consistent with the same idea about the favorable consequences - for themselves as well as others - of individuals' acting in their own self interest in the economic sphere. (Indeed, as post-millennialism went on to gain strength, in the $19^{\text {th }}$ century, salient economic/scientific advances like the laying of the first trans-Atlantic telegraph cable were greeted in many Protestant circles as having millenarian implications.)

Again to be clear, there is little or no evidence that Smith, or Mandeville, or any of the key thinkers in between except Hutcheson, personally held to any of these beliefs. The point, rather, is that they were continually exposed to arguments along these lines. Moreover, the fact that these beliefs were not yet fully accepted, either in England of the first quarter of the $18^{\text {th }}$ century or in Scotland of the century's third quarter, presumably made their salience and visibility all the greater. Most people devote little attention to ideas that everyone accepts and 
most take for granted (although, to be sure, Smith was a moral philosopher, and a probing and insightful one at that). What attracts attention and debate are claims that are disputed, and that bear implications over which there is tension. Arguments that cut against the officially received doctrine normally attract particular attention. Protestant theology was then undergoing a highly contested transition, and both Mandeville and Smith lived in the midst of it.

It would also be difficult to argue that any of these movements in religious thinking, away from orthodox Calvinism, was strictly necessary for the subsequent transition in economic thinking; Smith's ideas are powerful, and they stand on their own. Nor is there a case to be made that all four of these changes in religious thinking together were sufficient for this purpose. Mandeville and Smith came along, but they were not inevitable, at least not in their specific time. But in light of the readily apparent resonances between these new and contentious religious ideas and the key elements of the $18^{\text {th }}$ century transition in thinking about what became economics, there is ample ground to think, along Schumpeterian lines, that these changes in theological thinking helped create a new view of individuals' role in the world that was highly conducive to the Smithian revolution, and then to fostering its acceptance.

The role of religious thinking in shaping the emergence of economics as a recognizable intellectual discipline, with a field of inquiry and analytical apparatus distinctly its own, has also plausibly shaped the evolution of the field far beyond the foundational transition in the $18^{\text {th }}$ century that culminated in Smith's Wealth of Nations. Religious thinking strongly influenced the reception of the Smithian revolution, especially in America; the authors of the "political economy" textbooks that dominated the pre-Civil War period - John McVickar at Columbia, Francis Wayland at Brown, Francis Bowen at Harvard - were all either ordained clergymen or 
closely aligned with the one or another Protestant denomination. ${ }^{5}$ In the post-Civil War period, the movement that made economics into an ameliorative effort (amelioration, which presumes welfare criteria, is an inherently moral endeavor) was even more self-consciously inspired by religious thinking; many of the key figures who founded the American Economic Association, including John Bates Clark and Richard T. Ely, had their intellectual roots in the newly emergent Social Gospel movement of that time. Even today, many of the apparent puzzles surrounding our public debate over both economic fundamentals and economic policy - Why do most economists avoid models in which initial conditions are determinative of final outcomes? Why is there an “Anglo-Saxon model” of how to arrange a country’s economic affairs? Why do so many Americans who have no chance of inheriting money from a taxable estate passionately support abolishing "death taxes"? - plausibly reflect these and other continuing resonances.

Critics sometimes complain that belief in free markets, not just by economists but among ordinary citizens too, is a form of religion. It turns out that there is something to the idea - not in the way the critics mean, but in a deeper, more historically grounded sense. A better understanding of these lasting resonances, and their origin and subsequent implications as the economic context has changed over time, would enhance our appreciation of economics as a moral science.

\section{$\underline{\text { References }}$}

Bowen, Francis. 1856. Principles of Political Economy: Applied to the Condition, the Resources, and the Institutions of the American People. Boston: Little, Brown.

Davenport, Stewart. 2008. Friends of the Unrighteous Mammon: Northern Christians \& Market Capitalism, 1815-1860. Chicago: University of Chicago Press.

Hirschman, Albert O. 1977. The Passions and the Interests: Political Arguments for Capitalism 
Before Its Triumph. Princeton: Princeton University Press.

Howe, Daniel Walker. 1972. "The Decline of Calvinism: An Approach to Its Study." Comparative Studies in Society and History, 14 (June), 306-327.

Mandeville, Bernard. 1723 (1924). The Fable of the Bees: Or Private Vices, Publick Benefits. Ed., F.B Kaye. Oxford: Oxford University Press, 1924.

McVickar, John. 1830. Introductory Lecture to a Course on Political Economy. London: J. Miller.

Nicole, Pierre. 1696. “Of Charity and Self-Love.” In Moral Essayes. London: Samuel Manship.

Schumpeter, Joseph A. 1954. History of Economic Analysis. Ed., E.B. Schumpeter. New York: Oxford University Press.

Smith, Adam. 1976 (1759). The Theory of Moral Sentiments. Ed., D.D. Raphael and A.L. Macfie. Oxford: Oxford University Press.

Smith, Adam. 1976 (1776). An Inquiry into the Nature and Causes of the Wealth of Nations. Ed., R.H. Campbell and A.S. Skinner. 2 vols. Oxford: Oxford University Press.

Tillotson, John. 1748. "Of the Nature of Regeneration, and Its Necessity, in Order to Justification and Salvation." In The Works of the Most Reverend Dr. John Tillotson, Late Archbishop of Canterbury, vol. 5, sermon 106. Edinburgh: G. Hamilton.

Wayland, Francis. 1837. The Elements of Political Economy. New York: Leavitt, Lord.

\section{$\underline{\text { Notes }}$}

1. Quotations are from Smith (1776), p. 782, p. 99, p. 96.

2. See Hirschman (1977) for a concise summary of some of the more important antecedents.

3. See, for example, Howe (1972).

4. Quotations are from Tillotson (1748), p. 382.

5. Davenport (2008) provides a useful summary. 